\title{
El neobarroco y el lenguaje como la casa del ser: Aural, de Gilberto Castellanos
}

\author{
The Neo-Baroque and Language as the House of Being: \\ Aural by Gilberto Castellanos
}

\author{
Jason Lee Pettigrew \\ Middle Tennessee State University \\ Jason.Pettigrew@mtsu.edu
}

RESUMEN: Incorporando los conceptos de Severo Sarduy y de José Pascual Buxó sobre el neobarroco y la ambigüedad referencial, respectivamente, exploro cómo en Aural (2011) Gilberto Castellanos fractura la relación convencional entre signo lingüístico y referente, con la intención de comunicar una visión inédita de su experiencia vivida. Además, analizo el libro a la luz de algunos conceptos filosóficos de Martin Heidegger, como el "ser en el mundo" y el lenguaje como la "casa del ser". Basándome en su representación simbólica de las calles urbanas y la casa, aclaro su concepción de la poesía como un refugio acogedor de la existencia angustiosa, una morada lírica que brinda el amparo, la iluminación, la purificación y la solidaridad.

\author{
Palabras Clave: \\ Gilberto Castellanos; \\ poesía mexicana; \\ neobarroco; \\ Martin Heidegger.
}

KEYWORDS:

Gilberto Castellanos;

Mexican poetry;

Neo-Baroque; Martin Heidegger.
ABSTRACT: Incorporating the concepts of Severo Sarduy and of José Pascual Buxó of the neo-Baroque and referential ambiguity, respectively, I explore how in Aural (2011) Gilberto Castellanos fractures the conventional relationship between linguistic sign and referent, with the intention of communicating a novel vision of his lived experience. In addition, I analyze the book in light of some of Martin Heidegger's philosophical concepts, such as "being-in-the-world" and language as the "house of being". Basing my analysis on his symbolic representation of the urban streets and the home, I clarify his concept of poetry as a pleasant refuge from an anguished existence, a lyrical abode that provides shelter, enlightenment, purification, and solidarity.

recepción: 19 enero 2018.

aceptación: 20 agosto 2018. 


\section{Introducción}

Gilberto Castellanos (1945-2010), nacido en Ajalpan, Puebla, inició su labor poética con El mirar del artificio, con el que ganó el Premio Latinoamericano de Poesía, Colima, en 1982. ${ }^{1}$ En "La poesía neo-filosófica de Gilberto Castellanos", Alberto Julián Pérez pone de relieve la orientación neo-vanguardista del libro, que sigue las huellas de la poesía neo-filosófica y hermética de José Gorostiza y Octavio Paz (295). Además, como nos indica Óscar Rivera-Rodas, Castellanos explora el lenguaje poético desde su primera obra: "Desde sus inicios esta poesía, además de ser un lenguaje brillante es, asimismo, una reflexión sobre la teoría de la poesía del poeta. Es decir, sobre la concepción que el propio poeta tiene de lo que es poesía y de lo que es el oficio del poeta..." (2008: 8). A pesar de la calidad de su poesía, ha despertado poco interés crítico y merece más atención. En este análisis, exploro el estilo neobarroco y la teoría de la poesía en Aural, su poemario póstumo publicado en 2011. En primer lugar, incorporando los conceptos de Severo Sarduy y de José Pascual Buxó sobre el neobarroco y la ambigüedad referencial, respectivamente, exploraré cómo Castellanos fractura la relación convencional entre signo y referente, con la intención de comunicar una visión inédita de su experiencia vivida. Esta ofuscación del sentido de los textos ejemplifica su reflexión sobre la dificultad de "leer" y descifrar la realidad y convertirla en lenguaje poético. En segundo lugar, basándome en su representación simbólica de la calle y la casa a lo largo del poemario, pondré sus textos en diálogo con los conceptos de Martin Heidegger del "ser en el mundo" y el lenguaje como la casa del ser. Aclararé su concepción de la poesía como un refugio acogedor de la existencia angustiosa, una morada lírica interior que brinda el amparo, la iluminación, la purificación, el amor y la solidaridad. Este aspecto de la obra, como veremos, quizás revela una influencia de Las moradas del castillo in-

1 Gilberto Castellanos publicó dieciséis poemarios entre 1982 y 2017. Los primeros siete libros, publicados entre 1982 y 2007, se reunieron en la antología Como podar la luz (2008). Al morir en 2010, dejó listos para publicar varias obras más, que han salido gracias a la colaboración entre su viuda, Silva Castro, y la Benemérita Universidad Autónoma de Puebla. La publicación de su último libro pendiente, Fraselia (2017), finalmente completó su obra poética. 
terior (1588) de santa Teresa de Jesús (1515-1582), obra mística que explora la morada interior del alma. Además, esta concepción de la poesía revela que la "construcción" del hogar lírico, es decir, la creación del poema y la realización de su efecto edificante, también depende de la participación activa del lector, quien es invitado a ser "habitante" de aquella morada.

\section{El neobarroco, la ambigüedad referencial y la filosofía de Martin Heidegger}

A lo largo del poemario, Castellanos ofusca el sentido de los textos con un tejido complejo de lenguaje, utilizando algunos mecanismos del enmarañamiento neobarroco: la sustitución, la proliferación y la condensación de los signos lingüísticos. Según Severo Sarduy, el mecanismo de la sustitución escamotea y sustituye un significante, reemplazándolo por otro "totalmente alejado semánticamente de él y que sólo en el contexto [...] corresponde al primero en el proceso de significación" (9; énfasis en el original). Sarduy explica que en este mecanismo, la distancia semántica entre los términos representa una "falla entre lo nombrante y lo nombrado y el surgimiento de otro nombrante, es decir, metáfora. Distancia exagerada, todo el barroco no es más que una hipérbole" (10-11). Se observa un ejemplo de la sustitución en Aural en el poema "Silencio caudaloso" cuando "pestañas" sustituyen las alas de una libélula, significante que a su vez es reemplazada por "agua": "cruje sus pestañas de brisa / la libélula que no duerme, se vuelve agua" (Castellanos: 141, vv. 5-6). Otro ejemplo de la sustitución aparece en "Nanatierra hecha códice" cuando la ciudad (quizás durante el Día de Muertos) se convierte en cempasúchil (caléndulas) y luego en humo, sugiriendo la disipación del significante original: "ciudad mansa convertida en caléndulas de humo" (24, v. 30).

Un segundo mecanismo del barroco/neobarroco es la condensación, que Sarduy explica como "permutación, espejeo, fusión, intercambio entre los elementos de una cadena significante, choque y condensación de los que surge un tercer término que resume semánticamente los dos primeros" (15). La condensación de significantes se observa en varios textos de Aural: "tengo rostro de lama con un ramacielo / de semillatejido" ("Todo lo distante", Castellanos: 93, vv. 20-21; mi énfasis); "calle rutas angusmie- 
do" ("Hay caminos de hierro", 100, v. 31; mi énfasis); "brisahierro" ("Caliche contigua", 112, v. 15); "el espantaespíritus remueve plomadas / de musgo" ("Silencio caudaloso", 141, vv. 11-12; mi énfasis); "flagelo que se descuaja / en ella, yo, ellayó asidos, así dos, besan" ("Retrato de los rostros", 152, vv. 31-32; mi énfasis).

Por otra parte, Sarduy define un tercer mecanismo del enmarañamiento barroco/neobarroco, la proliferación, de esta forma:

Otro mecanismo de artificialización del barroco es el que consiste en obliterar el significante de un significado dado pero no reemplazándolo por otro, por distante que éste se encuentre del primero, sino por una cadena de significantes que progresa metonímicamente y que termina circunscribiendo al significante ausente, trazando una órbita alrededor de él, órbita de cuya lectura — que llamaríamos lectura radial— podemos inferirlo (11).

Castellanos emplea este mecanismo en "Las fuerzas de los meses", en que reflexiona sobre el paso del tiempo, mencionando el peso del pasado que todos Ilevamos en la conciencia. Ese pasado, o el "antes" que se menciona, es reemplazado por una serie de referencias sorprendentes que no parecen tener conexión entre sí:

Un antes pesa: fórmula de manos oscuras, tientos, rangos, rumbos, cuellos con sarro, pasos que se allegan un pliego, una llave, muestrarios donde se rompen los tacones... (122, vv. 20-23).

Por su parte, Néstor Perlongher señala la dificultad de decodificar los textos neobarrocos en su prólogo a Medusario, una compilación de poesía neobarroca:

Hay, con todo, una diferencia esencial entre estas escrituras contemporáneas y el barroco del Siglo de Oro. Montado a la condensación de la retórica renacentista, el barroco exige la traducción: se resguarda la posibilidad de decodificar la simbología cifrada y restaurar el texto "normal", a la manera del trabajo realizado por Dámaso Alonso sobre los textos de Góngora. Al contrario, los experimentos neobarrocos no permiten la traducción, la sugieren - estima Nicolás Rosa - pero se ingenian para perturbarla y al fin de cuentas destituirla (26-27). 
Esta perturbación del sentido se observa en muchos poemas de Aural. Los textos de Castellanos también se caracterizan por lo que José Pascual Buxó ha denominado la "ambigüedad referencial" y una falta de "isomorfismo" (es decir, uniformidad o semejanza) entre el lenguaje y la realidad referida. Buxó señala un tipo de poesía, comenzando con la vanguardia, que vacía las palabras de sus significados tradicionales, en búsqueda de más libertad poética: "Destruyendo los mecanismos que aseguran el isomorfismo con una representación de la realidad convenida y uniforme, se omitirá el grado cero del sentido [...] [E]l poeta optará por creer en una realidad sobrestante a la de la conciencia y de los sentidos, en un mundo sólo accesible a través de las palabras que no es, sin embargo, el mismo que ellas ordinariamente designan y transmiten" (15-16). Esta actitud hacia el lenguaje poético y la realidad se aproxima a lo que Óscar Rivera-Rodas designa la poética de la reducción fenomenológica en La modernidad y la retórica del silenciarse, lo cual reduce y "pone entre paréntesis", o tacha, los significados tradicionales de los signos (2001: 93) y las interpretaciones previas de la realidad para que los poetas puedan "mostrar el mundo a su manera" (76). Los autores vanguardistas realizan "la reducción de la percepción de la realidad y la re-ordenación de sus elementos reconstituyéndolos en esquemas que no coinciden con las estructuras tradicionales logocéntricas", intentando referir realidades nuevas y experiencias poéticas inéditas basadas en la percepción individual de los fenómenos de la realidad (98). Ésta ha sido la tarea del vanguardismo de las primeras décadas del siglo xx; no obstante, la poesía neo-vanguardista de Castellanos conserva esta aproximación subversiva al lenguaje denotativo.

Finalmente, pondré los textos de Aural en diálogo con los conceptos del filósofo alemán Martin Heidegger del "ser en el mundo" y el lenguaje como la casa del ser. En El ser y el tiempo (1927), Heidegger define la existencia del ser humano como "ser en el mundo" (64). El filósofo italiano Gianni Vattimo, en su valiosa Introducción a Heidegger, precisa este concepto de la siguiente manera:

El ser del hombre consiste en estar referido a posibilidades; pero concretamente este referirse se efectúa no en un coloquio abstracto consigo mismo, sino como 
existir concretamente en un mundo de cosas y de otras personas. El modo de ser medio y cotidiano del hombre, del cual decidimos partir, se presenta ante todo como ser en el mundo. El término alemán para designar 'existencia' es Dasein, literalmente "ser o estar aquí o ahí" (27).

En Carta sobre el humanismo (escrita en 1946), Heidegger también afirma que "[e]l lenguaje es la casa del ser", señalando que el ser humano existe principalmente en el lenguaje: "El lenguaje es la casa del ser. En su morada habita el hombre. Los pensadores y poetas son los guardianes de esa morada [...] El pensar trabaja en la construcción de la casa del ser que, como conjunción del ser, conjuga destinalmente la esencia del hombre en su morar en la verdad del ser. Este morar es la esencia del ser-en-elmundo" (2000: 11, 81).

Por otro lado, Heidegger resalta que el verdadero modo de ser de los "entes" (las cosas o fenómenos que existen en el mundo en que habita el ser) sólo es en relación con el ser humano; no existen "en sí" sino que "ante todo están en relación con nosotros como instrumentos" (Vattimo: 30). Que las cosas sean "instrumentos" se refiere a la idea de que sólo existen en relación a la conciencia del Dasein:

Instrumento en este sentido es también la luna, que al iluminar un paisaje nos sume en un estado de ánimo melancólico; y en general también la contemplación "desinteresada" de la naturaleza coloca siempre a ésta en un contexto de referencias, por ejemplo, de recuerdos, de sentimientos o por lo menos de analogías con el hombre y sus obras [...] Por otra parte, la totalidad de los instrumentos se da sólo en cuanto existe alguien que los emplea o puede emplearlos como tales, en cuanto está el Dasein, para el cual los instrumentos tienen su sentido, su utilidad [...] No hay mundo si no hay Dasein (Vattimo: 29-30).

Asimismo, Heidegger resalta el valor emotivo de las cosas y la afectividad de la existencia del ser humano "en el mundo": "El mundo se nos aparece siempre, originariamente, a la luz de cierta disposición emotiva: alegría, miedo, desinterés, tedio" (Vattimo: 38). También señala que el ser humano existe en el mundo siempre en relación a otros, el "estar-con", por lo que:

tiene la tendencia a comprender el mundo según la opinión común, a pensar lo que se piensa [...] Las opiniones comunes se comparten, no porque las haya- 
mos verificado, sino tan sólo porque son comunes. En lugar de la apropiación originaria de la cosa, se verifica aquí la pura ampliación y la pura repetición de lo que se ha dicho (Vattimo: 41-42; énfasis en el original).

Esta situación lleva al ser humano, por lo general, a experimentar el mundo e interpretar las cosas de una manera "inauténtica", pero para Heidegger uno puede acercarse a la "autenticidad" al evitar las opiniones comunes de las cosas y "relacionarse directamente" con ellas (Vattimo: 44).

Finalmente, Heidegger afirma que el Dasein es un "ser para la muerte" y que la existencia auténtica requiere una aceptación de la muerte:

La muerte, en efecto, como posibilidad de la imposibilidad de toda posibilidad, lejos de cerrar el Dasein, lo abre a sus posibilidades del modo más auténtico. Pero esto implica que la muerte sea asumida por el Dasein de un modo auténtico, que sea explícitamente reconocida por él como su posibilidad más propia. Ese reconocer la muerte como posibilidad auténtica es la anticipación de la muerte, que no significa un "pensar en la muerte", en el sentido de tener presente que deberemos morir, sino que más bien equivale a la aceptación de todas las otras posibilidades en su naturaleza de puras posibilidades [...] El concepto de anticipación de la muerte pone de manifiesto lo que es, precisa y concretamente, la existencia auténtica (Vattimo: 49, 51; énfasis en el original).

Castellanos refleja este aspecto de la filosofía de Heidegger en "Vivía ella con él", texto que subraya el hecho de que el ser humano nace para morir y hay que aceptar esa realidad:
$\ldots \ldots \ldots \ldots$. ¿ un bebé ha sonreído porque
la muerte acarició su mejilla? ¿si algún sordo
descubre a la muerte por fin sabrá que vivía ella con él? ...................... (69, vv. 8-11).

Como veremos, en Aural Castellanos poetiza su reflexión sobre la existencia y el lenguaje de manera similar a la filosofía de Heidegger: el ser humano existe con otros (familia, vecinos, el prójimo) en un mundo (la ciudad, la calle) poblado de fenómenos que experimenta a la luz de dis- 
tintas disposiciones emotivas, muchas veces negativas. Por medio de la reflexión y el lenguaje poético, intenta acercarse a las cosas de manera auténtica, evitando las interpretaciones "comunes" de los fenómenos. De igual manera, construye su morada lírica (la casa): un refugio del mundo que comparte con los seres queridos y con el lector y que ofrece el amparo, la iluminación, la purificación, el amor y la solidaridad. En adelante, analizaré varios textos de Aural que representan su estilo neobarroco, su ambigüedad referencial, la reducción fenomenológica del lenguaje y de la realidad, la posible influencia de la filosofía de Heidegger, y los intentos del poeta de construir tal morada lírica, señalando su afinidad con Las moradas del castillo interior de santa Teresa de Jesús.

\section{El neobarroco, la ambigüedad referencial y el silencio en Aural}

El título mismo del poemario, Aural, ejemplifica la ambigüedad referencial que caracteriza su discurso. Como tal, esta palabra no aparece en el diccionario; se trata de un adjetivo neológico derivado del sustantivo "aura" que puede significar un viento suave y agradable, aliento, soplo o quizás el halo o aureola que aparece en la cabeza de personajes sagrados en el arte. Ya que la reflexión sobre la naturaleza de la poesía y el lenguaje está en el corazón de la obra, es posible que "aural" se refiera al habla y a la enunciación de la poesía: ese aspecto del lenguaje que sólo son ondas de aire, sugiriendo también algo totalmente inasible que el poeta intenta captar con el lenguaje. Castellanos se refiere al viento, al aire o al aliento humano en varios poemas. En "Silencio caudaloso" reflexiona sobre su percepción sensorial de los sonidos de la naturaleza, como el zumbar de una libélula o el canto de los grillos, que pueblan el aire como enunciados inasibles como el agua y también silenciosos porque no comunican mensajes comprensibles: "cruje sus pestañas de brisa / la libélula que no duerme, se vuelve agua" (141, vv. 5-6). Sin embargo, el "aire imitador" (v. 14) del lenguaje poético intenta captar esos sonidos y reproducirlos como un fonógrafo, irónicamente llegando sólo al silencio en su casa de lenguaje: 
El aire imitador pasaría las páginas

de un libro con las hojas de arroz y renglones

desmoronables, aprendizaje penoso

de un fonógrafo de melancolía en el pretil.

¿Si lo inmóvil es la prehistoria del silencio

cuál rincón de mi casa lee sus pergaminos? (vv. 14-17, 31-32).

Este aire enigmático pesa sobre el espacio en que mora el poeta a lo largo del libro, y en un texto aun crea puertas en su casa de lenguaje: "¡Cuánto pesa el viento!... / ...el aire hace puertas" ("Los hijos regresan tarde", 71, vv. 26, 28). En otro texto, la voz lírica misma se vuelve aire, un ser "aural": "Un viento, flecha, llega de calendarios nuevos, / detiene su trayecto donde yo lo encuentro, / serán míos los escondites, me vuelvo aire y huyo" ("Ya estuve mañana", 74, vv. 1-3). En fin, el lector se queda con varias posibilidades interpretativas del título, algo que se reproduce en texto tras texto por su ambigüedad referencial.

Desde "Los días inseguros", el primer poema del libro, la voz lírica manifiesta la ambigüedad referencial de su lenguaje poético. Su enunciación es un aire o rumor que no llega a moldear una forma, configuración o sentido claros pero que forja sueños en la mente:

Como rumor, dueño del sendero, línea débil de hombres en lejanía y los pasos memoriosos de un aire de polvo sobre otro polvo en molde que nada configura pero está fraguando sueños ¿así comienza la sordera del musgo y la huella en otra pared mide lo callado? (11, vv. 1-6; mi énfasis).

Su casa de lenguaje reproduce aquellos rumores del viento que le provocan distintas disposiciones emotivas, ejemplificando su "ser en el mundo": "¿Será que mi casa también escucha y nombra / el taconeo del viento, la salud quizá ínfima / de la soledad, la risa suave de lo triste?" (vv. 7-9).

El título de "Ideas despalabradas" también refleja el estilo neobarroco del poemario y su violencia sobre el lenguaje. Si algo es descalabrado, recibe una herida en la cabeza; al transformar ese vocablo, Castellanos enfatiza que sus ideas o su pensar, el contenido de la etapa pre-lingüística del poema, sufren 
una violencia y una deformación al convertirse en lenguaje poético, destruyendo su isomorfismo con la realidad. Es decir, al expresarse, esas ideas no coinciden con el significado tradicional de las palabras, creando ambigüedad referencial y la dificultad de "traducir", o encontrar el sentido, de los enredos neobarrocos. El poema incluye varias interrogaciones enigmáticas: "¿Serán más los pasos que las respiraciones? / ¿más ideas despalabradas que los reflejos? / ¿todos los gritos unidos prenderían otro sol?" (18, vv. 25-27). En estos versos, "respiraciones" y "reflejos" se contraponen a "pasos" e "ideas despalabradas". Las respiraciones de un caminante impulsan sus músculos y su cuerpo, haciendo sus pasos físicos posibles. De igual manera, los reflejos de las palabras (los fenómenos de la realidad), estimulan las ideas del poeta, pero no se reproducen con exactitud en el lenguaje violentado. Recordemos que, según Heidegger, los fenómenos del mundo existen en relación con la conciencia del ser humano, quien vive más en el lenguaje que en la realidad. El poeta se pregunta si su caminar por la ciudad, su "ser en el mundo", existe más en relación con el lenguaje violentado que en relación con los fenómenos mismos. Parece preguntar si los gritos de su expresión poética podrían encender otro sol que sólo existiera en el mundo del lenguaje. En "Respiro de la transparencia", Castellanos yuxtapone la transparencia a la turbidez, enfatizando de nuevo la ambigüedad de su lenguaje poético: "¿Los habitantes de mi casa oirán pestañeos / de la quietud, el respiro de la transparencia? / En el agua turbia un reflejo se desnuda" (39, vv. 30-32). El poeta reta a los habitantes de su casa, quizás los lectores de su lenguaje/morada lírica, a percibir lo imperceptible, a oír la transparencia y ver los reflejos de los fenómenos en agua turbia. Esto nos recuerda el concepto de Néstor Perlongher de lo "neobarroso", "haciendo referencia directa al barro del Río de la Plata, que vendría a caracterizar la poética neobarroca, en tanto materia arcillosa, mutable, inestable, sin fijeza, fronteriza" (Cuba: 30). La idea de percibir la desnudez de un reflejo también armoniza con la idea de Heidegger de acercarse a las cosas de manera auténtica, despojándolas de toda interpretación previa.

"Por la calle, vamos" quizás representa más claramente el estilo "neobarroso" y la ambigüedad referencial en Aural. El texto contiene una serie de enunciados desarticulados e incoherentes que llegan al absurdo, como en los siguientes versos: 
dédalo la calle sus rechazos babas níquel y rajan puerta dentro la comprimen cubo tú estirar de la cepa un escupitajo cosas el sello rempujones inmediatez del miedo cemento blando grados hoy calor en vainas escalas el sacrificio túnel que los guiaría copa del espectro regreso del sudor a qué las casas guarniciones lo altísimo pozos va regurgita el tufo hay miseria sonsacada (99, vv. 14-22).

Según José Pascual Buxó, el isomorfismo entre lenguaje y realidad en la poesía de tradición clásica "asegura la comprensión y traductibilidad de los mensajes y tolera las alteraciones de los signos sólo hasta los límites previstos por un código de representaciones analógicas o metamórficas de lo real" (11). Así, por ejemplo, la poesía de Góngora no demuestra "un rechazo de la realidad" sino "un desacuerdo con la normalidad del lenguaje" (13). Sin embargo, muchos poetas vanguardistas (y por extensión, poetas neobarrocos) destruyeron ese isomorfismo, totalmente bloqueando la conexión isomórfica entre el lenguaje normal y la realidad convencional: "Pugnando por liberarse de un lenguaje pesadamente denotativo, dará en la ilusoria libertad del absurdo; agobiado por las férreas imágenes del mundo que las palabras de la tribu presuponen y difunden, el amotinamiento de ellas le proporcionará la sensación mallarmeana de haber encontrado al fin aquella pureza y aquella libertad tan largamente perseguidas" (16). De manera similar, hablando del vanguardismo, Óscar Rivera-Rodas afirma que "[e]l discurso de la modernidad, al reducir fenomenológicamente la lengua natural y poner entre paréntesis las significaciones de los referentes extralingüísticos, no refiere nada en el nivel de las descripciones del lenguaje convencional: no dice nada, se calla, se silencia, se vacía de las significaciones ordinarias. Apela a su propia retórica: la retórica del silencio" (2001: 281). Como en la filosofía de Heidegger, Castellanos busca una comprensión más auténtica de la realidad al relacionarse con los fenómenos sin interpretaciones previas, vaciando las palabras de su significado denotativo y destruyendo la sintaxis normal en busca de más libertad expresiva. Sin embargo, la falta de isomorfismo entre lenguaje y realidad impide la interpretación racional de muchos 
textos neobarrocos en Aural, a veces silenciando la función comunicativa del lenguaje.

\section{"Nanatierra hecha códice": orfandad urbana y discurso neobarroco}

Como los poemas analizados en la sección anterior, "Nanatierra hecha códice" utiliza algunos mecanismos del enmarañamiento neobarroco, como la condensación y la sustitución. El neologismo "nanatierra" constituye una condensación de la expresión popular "madre tierra", en que "madre" es reemplazada por "nana", nodriza o aya, la mujer que cuida a una criatura ajena. Es decir, la madre tierra se convierte en "nana tierra", sugiriendo que sus hijos son huérfanos o han sido abandonados, sin acceso a su madre verdadera. Además, es una "Nanatierra hecha códice", una nodriza que se convierte en un texto enigmático, enfatizando así cómo el ser humano "lee" su realidad y cómo el poeta convierte la tierra, y esa realidad entera, en lenguaje. No obstante, la mayoría de los códices precolombinos fueron destruidos, y los que quedan son indescifrables para un lector no experto por pertenecer al sistema precolombino de escritura pictográfica y por referirse a una cosmovisión distinta. De esta forma, el título "Nanatierra hecha códice" sugiere que aquella orfandad del ser humano también supone una pérdida de las raíces históricas y ancestrales. Al mismo tiempo, el estilo neobarroco y la ambigüedad referencial del texto producen un discurso hermético y difícil de descifrar como un códice precolombino. Es decir, la alusión a la escritura pictográfica refleja el estilo neobarroco del poemario y también revela la reflexión de Castellanos sobre la dificultad de "leer" y descifrar la realidad y convertirla en lenguaje poético. Según nos explica Néstor Perlongher, en la poesía neobarroca:

[e]l lenguaje, podría decirse, "abandona" (o relega) su función de comunicación, para desplegarse como pura superficie, espesa e irisada, que "brilla en sí": "literaturas del lenguaje" que traicionan la función puramente instrumental, utilitaria de la lengua para regodearse en los meandros de los juegos de sones y sentidos — "función poética" que recorre e inquieta, soterrada, subterránea, molecularmente, el plano de las significaciones instituidas, componiendo un artificio de plenitud enceguecedora y ofuscante [...] El referente aludido queda 
al final como sepultado bajo esa catarata de fulguraciones, y si su sentido se pierde, ya no importa (22-23).

Casi al final del poema, Castellanos emplea el mecanismo neobarroco de la proliferación para desarrollar la frase del título con una cadena de significantes enigmáticos. La voz lírica identifica esa "Nanatierra hecha códice" como la "casa" del ser humano, recordándonos la afirmación de Heidegger de que el lenguaje es la casa del ser. Al explorar y precisar aquella "casa", irrumpe en el discurso una proliferación de significantes herméticos que ofuscan el sentido: "Casa: hija de plomadas óseas, Nanatierra / hecha códice, llegas con tus rezos al canto, / el cempasúchil ha de ser tu altar cumplido" (24, vv. 24-26). Estos versos tal vez sugieran que la poesía misma, el canto florido ${ }^{2}$ que produce el poeta, es la casa del ser, un templo en que reza como ante un altar. Sin embargo, a fin de cuentas, la proliferación de significantes impenetrables y la ambigüedad referencial del discurso frustran el intento de "traducir" el texto, de luchar por alcanzar una exégesis racional. Así pues, "Nanatierra hecha códice" permanece enigmático, como si el lector intentara descifrar un códice precolombino.

Por otro lado, una variedad de elementos textuales de "Nanatierra hecha códice" trabajan juntos para comparar la escritura con un sacrificio ritual, una violencia sobre el lenguaje que sugiere la elaboración del texto neobarroco que sacrifica el isomorfismo entre lenguaje y realidad:

No quería salir de ti por no perderte, calle, ni deseaba llevar la piedra de lo escrito, algún dios aherrojado la llevará por mí; un ídolo de arena la roba de sol a sol, con él hago un sacrificio aunque mi corazón impida su maza ni otro manuscrito lo diga (24, vv. 1-6).

En otros versos, se mencionan atabales (v. 7) y teponaxtles (v. 21), tambores que sugieren el ritmo del poema. Asimismo, la voz lírica dice que roba y siembra "un destello", un resplandor fugaz que sugiere la semilla

2 En estos versos el poema quizás se refiera al concepto de la poesía en náhuatl, "in xóchitl in cuícatl", o "flor y canto". 
inspiradora de la poesía (v. 19). Parece que el poeta, mientras vaga por las calles del mundo urbano, encuentra su inspiración para producir su poema, convirtiendo su experiencia de la realidad en un discurso que subvierte el lenguaje denotativo, un proceso que se compara con la violencia de un sacrificio ritual. A continuación encontramos en varios versos la isotopía de la violencia, lo que puede sugerir la violencia ejercida sobre el lenguaje en la elaboración del texto: el sacrificio (v. 5), la maza del dios aherrojado (v. 6), la acción de pegar (v. 10), la cuchilla (v. 10), el puñal (v. 29) y "la macana de fuego" que "hace surgir la cifra" (v. 28). Esa cifra, su escritura en código, también evoca la cualidad esotérica e impenetrable de la escritura pictográfica de los códices nahuas.

Al nivel emotivo, el poema encierra la isotopía de la tristeza, las aflicciones, la angustia y el sufrimiento: el dios está "aherrojado" (v. 3), encadenado u oprimido; la voz lírica habla de "penas" (v. 7), "miserias" (v. 32) y un cometa que "nos empavorece" (v. 17). En otro verso, lamenta: "voy con los que pegan" (v. 10). Parece que los habitantes que vagan por las calles de la ciudad sufren de orfandad, pavor, angustia y miserias, aunque sea una ciudad "mansa", convertida en lenguaje florido: "ciudad mansa convertida en caléndulas de humo; / con sus habitantes brotan ríos obsidianos, / hogueras muy altas ya coronan las miserias" (vv. 30-32). Este último verso del poema, que también sirve como subtítulo de la primera sección del libro, emplea el mecanismo neobarroco de la sustitución cuando las "hogueras" son sustituidas por la acción de "coronar". Visualmente hay una condensación de imágenes, un reflejo visual, ya que las Ilamas de una hoguera pueden parecerse a la forma de una corona. Además, la acción de coronar señala que un soberano va a comenzar a reinar. De ahí que el último verso, "hogueras muy altas ya coronan las miserias", podría traducirse como "las miserias reinan como hogueras" en el espacio urbano del poemario.

\section{La calle: la inhospitalidad y el angustioso "ser en el mundo"}

En Aural, Castellanos a menudo retrata a seres humanos que vagan por las calles del mundo urbano y sufren de soledad, vacío, abandono y desarraigo espiritual. Heidegger afirma en El ser y el tiempo que "[l]a inhos- 
pitalidad es la forma fundamental, si bien cotidianamente encubierta, del 'ser en el mundo'" (302), también señala que "[e]n la angustia le va a uno 'inhóspitamente' [...] 'inhospitalidad' quiere decir al par 'no estar en su casa'" (207). Este estar arrojado al mundo o abandonado en un ambiente inhóspito, expulsado de la morada acogedora, produce la angustia del ser en el mundo: "El 'estado de abandono' del 'ser ahí' a sí mismo se muestra con original concreción en la angustia" (212). Las calles urbanas en Aural reflejan muy bien estos conceptos heideggerianos. En "Los días inseguros", el primer poema del libro, la voz poética pregunta: “¿Cómo hablar de sangre apasionada si un hombre / sin amor pierde su alma y vaga enceguecido? [...] / ya pasan su trayecto los días inseguros" (11, vv. 19-20, 24). A lo largo del poemario, Castellanos retrata a seres solitarios, sin amor ni solidaridad con el prójimo, destacando la incertidumbre que domina su existencia angustiosa.

En "Contigo tus distancias", Castellanos traza este ambiente inhóspito en que el ser humano desarraigado vaga, un espacio oscuro y frío donde sólo el rencor llena el vacío y su única compañía es su propia sombra:

Lo que muerde a la noche son colmillos del frío; la herida que al hombre solitario congela expande con delectación su rencor al sitio sin muebles ni bujías encendidas, rencor fatuo presentido donde una sombra espera y es la suya (12, vv. 14-18).

Andar por las calles inhóspitas se compara con cavar bajo la tierra como un topo, lo cual separa al ser humano de la luz, produce un cansancio asfixiante y esconde su identidad auténtica ${ }^{3}$ bajo una máscara:

La calle abre, desplaza como topo bajo techumbres de la luz el cuerpo encenizado; al cansancio con que arrastra sus jorobas, yelmo asfixiante, nos ha entregado una máscara (vv. 22-25).

3 En Introducción a Heidegger, Vattimo señala que un tema fundamental de El ser y el tiempo es "la distinción entre existencia auténtica y existencia inauténtica" (40). Precisa que "la existencia inauténtica representa la situación negativa y de dispersión en que se encuentra siempre el Dasein y de la cual debe salir reencontrándose a sí mismo [...] es pues una situación de la que se trata de cobrar conciencia" (53). 
De manera similar, en "Río del vértigo" la existencia angustiosa en la urbe, representada como una maqueta en el poema, transforma a los seres humanos en angulas en lata y produce su soledad y alienación:

alguien apurado que algún día podrá medir
esa maqueta donde todos los hombres vayan
colgantes del cerebro moviéndose sin lazo,
amillonados en los cuadros del pavimento;
en casas como latas, angulas como hombres
que se ven cara de angula por acumular
hasta los huesos al espíritu, cocer piedras,
aceites de cal para probar otras angustias;
que muerdan lo sucio polvoso de la soledad,
marasmo de todos cuando se contemplan solos (48, vv. 21-30).

Irónicamente, a pesar de compartir aquel ambiente inhóspito con miIlones de otros seres, sólo pueden contemplar su propia soledad.

Castellanos explora de nuevo esta existencia inauténtica y angustiosa en "El teatro de la calle", en que aquel espacio inhóspito se apodera de las personas y las convierte en una especie de momias: "¿Se adueña de nosotros el teatro de la calle / y de ahí regresamos ya empolvados, quizá momias / con pedazos del grito que nos amortaja" (104, vv. 1-3). Andan por la urbe con sus rostros alterados por tragedias y soledad: "El humo acomoda caras de tragedia niña, / tras los almidones del rostro subvertido, / tras el gesto la soledad que la calle dicta" (vv. 13-15).

Parece que no existe ningún escape de la soledad, la incertidumbre, la angustia y el vacío que agobian al ser humano y penetran en su mundo interior. Sin embargo, en "Dimensión terrible de la noche", el poeta reafirma que nos acompaña y que comparte la angustia:

se adentra y está frente a un paraje sin sentidos que tiene la dimensión terrible de la noche y otra vez las paredes del vacío, ...

Estás conmigo, inquilina de incertidumbres... $(49$, vv. 3-5, 8). 
Los seres enfermizos que siguen por su camino, vagando por las aceras, sólo pueden imaginar la "salud" que podría infundirles el "contagio" de la belleza natural, representada por el chicalote, una planta con propiedades medicinales:

...contagios nítidos del chicalote recién abierto a los ojos del amanecer; salud que imaginan quienes agonizantes emprenden otra vez por aceras del émbolo

("Contigo tus distancias", 12, vv. 5-8).

En síntesis, las calles del mundo urbano representan un espacio corrompido pero con esperanza de recobrarse. Por ejemplo, en "Huellas de los hábitos", la voz poética afirma que la iluminación de un nuevo amanecer llegará a este espacio sombrío: "La calle oscura recogió una violeta procaz, / deshidratada en la esquina de un brasero lento, / magnolias pútridas lo niegan, ya vendrá el alba" ("Huellas de los hábitos", 23, vv. 1-3).

\section{La casa acogedora: morada lírica del ser}

Como se argumentó en la sección anterior, a lo largo de Aural Castellanos plasma un ambiente urbano en que reinan la incertidumbre, la angustia y el derrumbe espiritual. Este espacio angustioso y opresivo contrasta con la casa del poeta, su recinto interior ameno con su "[c]imiento de palabras" ("Las horas pobres", 20, v. 24). Recordemos que para Heidegger "[e]l lenguaje es la casa del ser" (2000: 11). Esta idea conecta bien con la concepción de la poesía que encarna Castellanos en Aural: la poesía es un refugio acogedor, una morada lírica que brinda el amparo, la iluminación, la purificación, el amor y la solidaridad. Comentando este concepto heideggeriano del lenguaje como la morada del ser, María del Rosario Gazmuri Barros insiste en la creación de un espacio más acogedor, casi sagrado, en la palabra poética:

Si la penuria del mundo moderno es la reducción de las cosas a meros objetos, y, por tanto, la desaparición del mundo, el desafío del poeta es la inauguración de un nuevo mundo, en el que se pueda, realmente, habitar, morar, en el que 
el hombre pueda tener arraigo. Es la palabra, por tanto, la que posibilitaría el arraigo, pero la palabra esencial, la que esencia a la cosa como lo hace la palabra poética [...] Son los poetas los que establecen un diálogo en torno a la cosa, que ya no es mero útil, sino que, desde la palabra que la nomina, establece un espacio sagrado (121).

Este tipo de morada contemplativa alegórica también tiene antecedentes en la literatura mística, por ejemplo, en Las moradas del castillo interior de santa Teresa de Jesús. En esta obra, santa Teresa "se basa en una alegoría: el castillo con siete moradas en cuyo centro se encuentra Dios representa el alma; a su vez, el alma misma penetra en él y recorre las estancias hasta alcanzar en la última el matrimonio místico" (Hernando Morata: 32). Sin duda, estas moradas interiores que recorre el alma en la obra de santa Teresa se parecen a la casa metafórica de contemplación poética que cimienta y poetiza Castellanos a lo largo de Aural.

En "Historias del cristal amado", el autor describe su casa como "el sitio del alma" (96, v. 29), sugiriendo un viaje hacia el interior a la manera de santa Teresa y enfatizando así cómo se acerca a su ser más auténtico por medio de la contemplación poética. Además, su casa es un himno sagrado y un espacio de bendición y descanso que resguarda a sus habitantes de la inclemencia:

La casa bendice sus rincones como un himno irrepetible, como inclemencia vencida, sin mañana, como descanso de arenas frescas y sencillez de dos, testigo la noche, tibias las palabras, huella enmudecida de la sombra que oye historias del cristal amado; ella crece rodeada de sus constelaciones de mujer que impone un paredón a las incertidumbres; la calle no se atreve: son antorchas muy amplias, ese reino de las armas nobles, alfarda fuerte (vv. 6-15).

Es decir, los maderos fuertes del techo (las alfardas) y las paredes simbólicas de su refugio lírico protegen a sus habitantes de las calles inhóspitas donde reina la incertidumbre. Asimismo, los seres queridos que habitan este refugio ofrecen amor y apoyo. 
Para acentuar la importancia de la casa acogedora en el libro, CasteIlanos finaliza cada sección (excepto la quinta) con un poema que nos invita a descansar en este espacio grato, el hogar lírico del poeta. Estos poemas edificantes sustituyen el tono angustioso y decaído que predomina en otros textos. En "Solar de mi casa", "Mantel de mi casa", "Tierra de mi casa", "Parcela de mi casa", y "Amuletos de mi casa" (poemas que finalizan varias secciones del libro) el autor cristaliza el propósito de su labor poética en Aural: alcanzar la paz y la sabiduría profundas que ofrece la contemplación poética y compartir esta morada lírica para consolar a aquellas personas abatidas y solas que vagan por las calles del mundo moderno. La casa amena y la hospitalidad del poeta ofrecen el reposo, la convivencia y la solidaridad para recobrarse.

En la mayoría de los poemas antes citados, el autor emplea la epífora al repetir el título del poema al final de cada verso, produciendo un efecto de rezo o plegaria. ${ }^{4}$ En "Solar de mi casa", que concluye la primera sección, esta plegaria sugiere que habitar la acogedora morada lírica del poeta puede vencer la inhospitalidad y la angustia del "ser en el mundo", ofreciendo un espacio donde reinan la bondad y el amor:

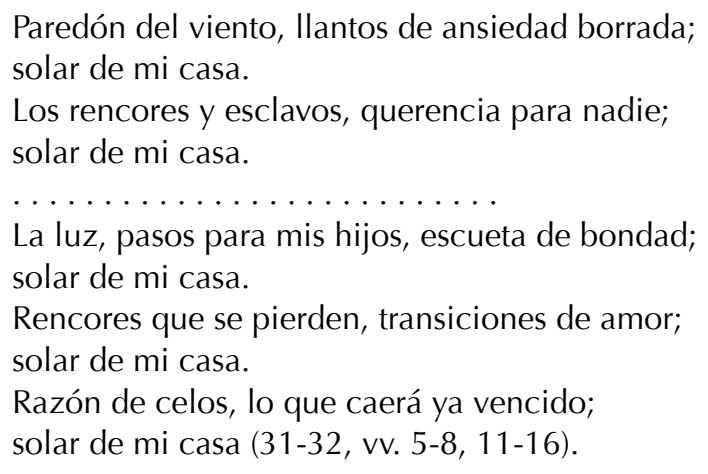

El mundo se representa como lenguaje, lo que nos recuerda que, según Heidegger, el ser humano vive más en el lenguaje que en la realidad: "Crecerán su idioma las lejanías y el silencio [...] / Si vuelves traerás contigo

4 Como indica Helena Beristáin en Diccionario de retórica y poética, "[s]i se prolonga, la repetición epifórica tiende a adquirir un efecto de letanía" (193). 
el mundo que te habló" (vv. 19, 25). Habitar este espacio de reflexión y sosiego también ofrece la iluminación: "Se postran los ojos en lo alto, iluminado" (v. 17). La iluminación de tal reflexión poética conecta al ser humano con su alma y su identidad auténtica: "Tictac de la sangre, tráfico denso del alma; / solar de mi casa" (vv. 43-44).

En "Mantel de mi casa", que finaliza la segunda sección, también se observa el contrapunto grato del espacio urbano donde predominaba el vacío espiritual. Como en Las moradas de santa Teresa, Castellanos elabora en Aural una división entre el mundo exterior, un espacio laberíntico de peligro y sufrimiento, y el mundo interior de contemplación. ${ }^{5}$ Ahora los versos del poeta reflejan el sustento ofrecido en su mesa lírica. Las imágenes desagradables de la ciudad se desvanecen ante el esplendor natural que rodea la casa y la mesa abundante que la voz lírica ha tendido. De nuevo, la epífora crea un ritmo melódico y equilibrado, de plegaria o canto religioso, que contrasta con el acento disonante de otros textos. Esta repetición enfatiza el sustento y la convivencia que la voz lírica nos ofrece al tendernos su poema como una mesa abundante:

Dulzores dormidos en las harinas de mayo; mantel de mi casa.

Sabores que se reparten los panes de marzo; mantel de mi casa.

Perfumes verdes, panes, en vuelo la cocina; mantel de mi casa.

Guitarras, canción rubia de uvas desgranadas; mantel de mi casa.

La noche, las copas y las manos, transparentes; mantel de mi casa (56-57, vv. 9-10, 32-33, 50-55).

5 Como afirma Juan Miguel Prieto Hernández, santa Teresa claramente delimita estos dos espacios en su elaboración del símbolo del castillo interior: "la configuración espacial del castillo [...] constituye el límite o frontera que separa el exterior, del comienzo de la vida interior del alma. Santa Teresa establece, mediante esta división, una clara diferenciación entre el mundo externo, ajeno al alma, y el inicio del camino de perfección" (797). 
La convivencia de la sobremesa vence la soledad de otros textos: "No saborea, quieta, la silla solitaria" (v. 42). El frutero lleno de manzanas es un "maestro que prende lámparas rojas" (v. 15); y aun las "migas de luz" que quedan en la mesa después de la sobremesa parecen vencer las tinieblas de otros textos (v. 64). Así, las visitas en esta morada lírica se purifican y se recobran, saciándose el hambre y la sed espirituales con la ensoñación del poeta que nos devuelve la esperanza: "El agua purifica olvidos, unge los labios... Té madrugado, poción esperanzada y amarga" (vv. 23, 46).

Similarmente, al final de la cuarta sección, en "Parcela de mi casa", el poeta enfatiza de nuevo la iluminación proveniente de su morada lírica: "Bienaventuranza, luz amplia que los bendice; / parcela de mi casa" (105106 , vv. 23-24). Este sitio placentero reemplaza la duda y la incertidumbre con la fe: "Diamante del agua, camina la fe mañana; / parcela de mi casa" (vv. 33-34). La ensoñación del poeta se vuele realidad al compartirse con el prójimo, reemplazando la soledad de otros textos con la solidaridad: "Los brazos que se funden, trigal de los encuentros... / Un sueño se hace real, frente con la frente; / parcela de mi casa" (vv. 29, 49-50).

En "Amuletos de mi casa", el último texto del poemario, Castellanos enfatiza el poder curativo de la convivencia en esta morada lírica, sugiriendo que provee sustento espiritual y la protección sobrenatural o el poder curativo de un amuleto. El texto asocia la casa del poeta con una serie de símbolos positivos que proveen sustento, luz, cura, amparo y protección:

Verano de mi casa despierto en la sandía.

Recetas de mi casa que al adobe curan.

Amuletos de mi casa colgados del alba.

Graneros de mi casa con que viajó el silo.

El agua de mi casa es mar en sus corrientes.

Mansión de mi casa la que para sí quiere.

Amigos de mi casa el aire y su bosque blanco

(153-154, vv. 4-6, 19, 24-26).

Además, la casa lírica y el lenguaje curativo que el poeta comparte con sus lectores tienen el poder de vencer las divisiones entre los seres 
humanos, simbolizadas por alambrados: "Las letras de mi casa vencen alambrados" (v. 15). El espacio urbano inhóspito y angustioso, donde el ser humano sufría la soledad y el desarraigo espiritual en su existencia inauténtica, se ha desvanecido, reemplazado por el lenguaje poético, la morada lírica interior que lo acerca a la paz, a la sabiduría y a una existencia más auténtica. La casa lírica brota de su interior y transforma el semblante del ser humano, entrando en su identidad como plantas injertadas y revelando su rostro verdadero: "Injertos de mi casa metidos en el rostro" (v. 11).

Por otra parte, "Luminosidad hecha esperanza" enfatiza de nuevo el amparo que ofrece la morada lírica y señala cómo el pensamiento poético puede proveer una sabiduría profunda. Los primeros versos del poema destacan que la casa del poeta ofrece refugio e iluminación: "Casa de las tardes y mantel de luceros, / refugio de adobes tristes" (47, vv. 1-2). Este espacio ameno reemplaza la inhospitalidad y la angustia de otros textos con la fertilidad, la esperanza y la iluminación: "bajo la luminosidad hecha esperanza / crece un clavel y fija sus límites el día" (vv. 19-20). Asimismo, el texto reflexiona sobre el pensamiento poético y cómo esa "casa" de lenguaje que habita el ser humano "construye" su existencia: "Nos construyes, casa, con vuelos de mil insectos / en el bosque de la mente" (vv. 12-13). En fin, el poema explora el "mural de nuestro pensamiento" (v. 23). De manera similar, Heidegger insiste en que el pensamiento y el lenguaje construyen nuestro ser en el mundo. Recordemos que en Carta sobre el humanismo Heidegger dice:

El pensar lleva a cabo la relación del ser con la esencia del hombre [...] en el pensar el ser llega al lenguaje. El lenguaje es la casa del ser. En su morada habita el hombre. Los pensadores y poetas son los guardianes de esa morada. Su guarda consiste en llevar a cabo la manifestación del ser, en la medida en que, mediante su decir, ellos la llevan al lenguaje y allí la custodian [...] El pensar trabaja en la construcción de la casa del ser que, como conjunción del ser, conjuga destinalmente la esencia del hombre en su morar en la verdad del ser. Este morar es la esencia del ser-en-el-mundo (11-12, 81).

Y según precisa Vattimo en Introducción a Heidegger, "[e]l pensamiento es fundamentalmente una escucha del lenguaje en su originaria condi- 
ción poética, esto es, en su fuerza de fundación y de creación: por eso, el elemento en el cual se desarrolla nuestra existencia es la proximidad de pensar y poetizar" (120). Castellanos parece afirmar algo parecido en Aural: el pensamiento poético y la acogedora morada lírica que construye en la mente nos acercan a nuestro ser auténtico.

Finalmente, en "Trozos de un día borrado" el poeta reflexiona sobre el poder curativo de su refugio lírico y la salud espiritual que brinda. Primero, señala que la gente llega a casa cargando a cuestas la angustia y el quebranto espiritual producidos por su tiempo en el entorno inhóspito de las calles: "¿Qué traen a casa los espíritus quebrados?" (127, v. 19). No obstante, habitar en la morada lírica restaura la palabra poética, descrita como la alacena del corazón, infundiendo fe como sustento espiritual:

\author{
La fábrica del corazón respira, no aguarda, \\ instala entre sus vinos una luna franca, \\ una palabra restaurada, su alacena, \\ siente cada muro de la casa como pulso \\ hermano, territorio de fe sin lo negro \\ de la calle ni rebabas crudas del insomnio (vv. 27-32).
}

Así, en varios poemas edificantes a lo largo del libro, Castellanos nos aparta de aquel ámbito exterior inhóspito que infunde angustia, incertidumbre y quebranto espiritual, guiándonos por las tinieblas de las calles urbanas hacia la puerta de la morada interior, un sitio ameno donde compartimos la fraternidad, la fe y la esperanza. En esto, la casa simbólica de Castellanos quizás revele, como ya se sugería una influencia de obras místicas como Las moradas del castillo interior de santa Teresa, en que el alma se adentra en su peregrinación por "un laberinto textual con forma de castillo" hasta lograr la iluminación divina (Carrión: 281).

Además, después de aceptar ese refugio temporal, al salir de nuevo a las calles, los habitantes de su morada lírica se pueden llevar el sustento espiritual (la fruta y el agua compartidas), la iluminación y la solidaridad que su estancia les ha brindado:

Donde vayan los habitantes de mi casa

llevarán sobre la frente los ojos extensos 
de las puertas, lo frutal del mosaico, el agua que una cifra cruza en el pecho y eleva su raíz ("Ideas despalabradas", en Castellanos: 18, vv. 1-4).

En fin, estos textos edificantes parecen el reflejo de los comentarios del filósofo Hans-Georg Gadamer al esclarecer el concepto de Heidegger del lenguaje poético como la casa del ser:

me sigue pareciendo cierto que la lengua no es sólo la casa del ser, sino también la casa del ser humano, en la que vive, se instala, se encuentra consigo mismo, se encuentra con el Otro, y que la estancia más acogedora de esta casa es la estancia de la poesía, del arte. En escuchar lo que nos dice algo, y en dejar que se nos diga, reside la exigencia más elevada que se propone al ser humano. Recordarlo para uno mismo es la cuestión más íntima de cada uno. Hacerlo para todos, y de manera convincente, es la misión de la filosofía (156).

\section{Conclusiones: lectores y habitantes de la morada lírica}

Como se ha mostrado en este estudio, Castellanos se sirve de los mecanismos de la artificialización neobarroca, con sus giros enigmáticos, quizás para reflejar el caos de la vida urbana moderna y para buscar una expresión inédita de su realidad. El poeta a menudo utiliza estos giros neobarrocos en textos que describen una urbe inhóspita donde reinan la angustia y la incertidumbre, una representación que se parece al concepto del "ser en el mundo" de Martin Heidegger. Estos poemas oscuros y enigmáticos contrastan con otros textos claros y edificantes que ofrecen un refugio para recobrarse. Con su representación simbólica de la casa a lo largo de Aural, Castellanos revela su concepción de la poesía como un refugio interior de la orfandad, las miserias, el caos y la soledad de la vida moderna, una morada lírica que brinda la iluminación, la purificación y la solidaridad. Se trata de una poesía neo-filosófica, para utilizar el término de Alberto Julián Pérez, cuya lectura se puede enriquecer, como hemos visto, al ponerla en diálogo con el proyecto filosófico de Heidegger y con sus antecedentes místicos. 
Además, el poeta invita a las personas desarraigadas y solitarias, sus lectores, a acompañarlo en su refugio lírico. Así, los receptores de su lenguaje poético comparten su experiencia y se convierten en "habitantes" de su casa, una expresión que se repite a menudo en el poemario. Castellanos afirma que su edificación lírica puede amparar a sus habitantes y resguardarlos de su medio inhóspito: "Los habitantes de mi casa desdoblan, rompen / la ruindad y el vacío veraz en la tormenta; / es amuleto poderoso estar adentro" ("Huellas de los hábitos", 23, vv. 30-32). Sin embargo, ya en el primer poema del libro, el poeta reconoce que la "construcción" de este hogar lírico requiere la participación activa de sus lectores:

De un hato de fechas derramadas ¿cuál será la que adopte mi cuerpo, la mente y sus andanzas para que al fin construyamos juntos las paredes donde se alojen horas, lumbre del oficio y la moneda líquida que la sal adeuda?

("Los días inseguros", 11, vv. 10-14; mi énfasis).

En estos versos, Castellanos parece señalar que su cuerpo (sus sentidos) y su mente trabajan juntos en el oficio de escribir poesía. Sin embargo, el "nosotros" de "construyamos" también puede incluir al receptor del poema, cuya lectura es necesaria para construir las paredes de la morada lírica, o completar el texto con su lectura.

Castellanos parece incluir al receptor en el último verso del poema que concluye el libro, "Amuletos de mi casa". En este verso final, el autor reconoce que su visión del refugio lírico no deja de ser ilusoria, una casa a medio construir que sólo se terminará con la convicción y el esfuerzo de sus receptores: "¿Algún día veremos esta casa terminada?" (154, v. 32). A la vez, el poeta lamenta la falta de fe que observa en la gente: "El sol tan cerca de mi casa y aún dudamos" (v. 16). En otras palabras, el poeta puede invitar a sus receptores a rehuir su medio inhóspito y recobrarse conviviendo en su morada lírica, pero ellos mismos tienen que pasar por su puerta y creer en el efecto curativo de su poesía. 


\section{Bibliografía}

Beristáin, Helena. Diccionario de retórica y poética. $3^{a}$ ed. México: Porrúa, 1992.

Buxó, José Pascual. César Vallejo: crítica y contracrítica. México: Universidad Nacional Autónoma de México. Instituto de Investigaciones Bibliográficas, 1992.

CARRIÓN, MARÍA M. Arquitectura y cuerpo en la figura autorial de Teresa de Jesús. Barcelona: Anthropos, 1994.

Castellanos, Gilberto. Aural. Puebla: Benemérita Universidad Autónoma de Puebla, 2011.

CubA, Pablo De. La usina del lenguaje: Teoría de la poesía neobarroca. College Station TX: Texas A\&M U, PhD dissertation, 2013.

Gadamer, Hans-Georg. La herencia de Europa. Pilar Giralt Gorina (trad.). Barcelona: Ediciones Península, 1990.

Gazmuri Barros, María del Rosario. El papel de la palabra poética en el proyecto filosófico de Heidegger y en la hermenéutica de Gadamer. Madrid: Universidad Complutense de Madrid, PhD dissertation, 2016.

Heidegger, Martin. El ser y el tiempo. José Gaos (trad.). México: Fondo de Cultura Económica, 1986.

Heidegger, Martin. Carta sobre el humanismo. Helena Cortés y Arturo Leyte (trads.). Madrid: Alianza Editorial, 2000.

Hernando Morata, Isabel. "El símbolo del laberinto en Las moradas del castillo interior, de santa Teresa de Jesús", en Hipogrifo. Revista de literatura y cultura del Siglo de Oro. Vol. 4, núm. 2 (2016): 31-41.

Pérez, Alberto Julián. "La poesía neo-filosófica de Gilberto Castellanos", en Inti. Revista de Literatura Hispánica. Vol. 1, núm. 43 (1996): 295-301.

Perlongher, Néstor. "Neobarroco y neobarroso". Prólogo a Medusario. Muestra de poesía latinoamericana. Roberto Echavarren et al. (sel.). México: Fondo de Cultura Económica, 1996. 19-30.

Prieto Hernández, Juan Miguel. "La construcción alegórica de la séptima morada", en Estado actual de los astudios sobre el Siglo de Oro. Actas del II Congreso Internacional de Hispanistas del Siglo de Oro. Tomo II. Manuel García Martín (ed.). Salamanca: Universidad de Salamanca, 1993. 795-801.

RIVERA-RODAS, ÓSCAR. La modernidad y la retórica del silenciarse. Xalapa: Universidad Veracruzana, 2001.

Rivera-Rodas, ÓsCar. "La poesía de Gilberto Castellanos". Prólogo a Gilberto Castellanos. Como podar la luz, 1982-2007. Puebla: Secretaría de Cultura del Gobierno del Estado de Puebla, 2008. 7-53.

Sarduy, Severo. El barroco y el neobarroco. Buenos Aires: El Cuenco de Plata, 2011.

Vattimo, GianNi. Introducción a Heidegger. Alfredo Báez (trad.). Barcelona: Editorial Gedisa, 2002. 


\section{Jason Lee Pettigrew}

Se doctoró en la Universidad de Tennessee (EE.Uu.), y actualmente es docente en Middle Tennessee State University, donde da cursos de lengua y literatura. Su principal línea de investigación es la poesía hispanoamericana del siglo xx. Entre sus principales publicaciones se encuentran artículos sobre la poesía de Carlos Pellicer y de José Pascual Buxó y una comparación entre la poesía neoépica post-vanguardista de Pablo Neruda y la de Jorge Enrique Adoum. 